\title{
Use of gases to improve survival of Bifidobacterium bifidum by modifying redox potential in fermented milk
}

\author{
B. Ebel, ${ }^{\star} \dagger$ F. Martin, ${ }^{*}$ L. D. T. Le, ${ }^{*}$ P. Gervais, ${ }^{\star}$ and R. Cachon ${ }^{* 1}$ \\ *Laboratoire de Génie des Procédés Microbiologiques et Alimentaires, AgroSup Dijon, Université de Bourgogne, site INRA, \\ 17 Rue Sully, 21065 Dijon, France \\ †Senoble Holding, 30 rue des Jacquins, 89150 Jouy, France
}

\section{ABSTRACT}

The aim of this work was to study the effect of the oxidoreduction potential, modified using gas, on the growth and survival of a probiotic strain, Bifidobacterium bifidum, and 2 yogurt strains, Streptococcus thermophilus and Lactobacillus delbrueckii ssp. bulgaricus. Three fermented milks were manufactured with an initial oxidoreduction potential value adjusted to +440 $\mathrm{mV}$ (control milk), $+350 \mathrm{mV}$ (milk gassed with $\mathrm{N}_{2}$ ), and $-300 \mathrm{mV}$ [milk gassed with $\mathrm{N}_{2}$ plus $4 \%$ (vol/vol) $\left.\mathrm{H}_{2}\left(\mathrm{~N}_{2}-\mathrm{H}_{2}\right)\right]$. Acidification profiles, growth during milk fermentation and survival during storage at $4^{\circ} \mathrm{C}$ for 28 $\mathrm{d}$ were determined. This study showed that fermented probiotic dairy products made from milk gassed with $\mathrm{N}_{2}$ and, more particularly, those made from milk gassed with $\mathrm{N}_{2} \mathrm{H}_{2}$ were characterized by a significant increase in B. bifidum survival during storage without affecting the fermentation kinetics and the survival of Strep. thermophilus and L. delbrueckii ssp. bulgaricus.

Key words: bifidobacteria, redox potential, survival, fermented milk

\section{INTRODUCTION}

Bifidobacteria are probiotic bacteria isolated from the human gastrointestinal tract. They are the most prevalent microbes in the large intestine but are also implanted throughout the distal jejunum and ileum in the small intestine (Kerckhoffs et al., 2006). The large intestine is mainly anaerobic with a low oxidoreduction (redox) potential $\left(\mathbf{E}_{\mathbf{h}}\right)$, in the range of -200 to $-300 \mathrm{mV}$ in the colon lumen (Wilson, 2008). The $\mathrm{E}_{\mathrm{h}}$ plays an essential role in microbial cell physiology (Pearson and Walker, 1976; Unden et al., 1990). Obligate aerobes are metabolically active in an environment with a positive $\mathrm{E}_{\mathrm{h}}$, whereas obligate anaerobes require a negative $\mathrm{E}_{\mathrm{h}}$. In the large intestine, many aerobes and

Received September 22, 2010

Accepted January 11, 2011.

${ }^{1}$ Corresponding author: remy.cachon@u-bourgogne.fr facultative anaerobes (enterobacteria, streptococci) are responsible for creating a reduced environment suitable for the establishment of obligate anaerobe bacteroides and bifidobacteria (Mackie et al., 1999).

Probiotic species that normally reside in the human gut (bifidobacteria, lactobacilli) have been associated with beneficial health properties, such as improving general gut health and positively influencing the development and activity of the immune system (Fuller, 1991; Kaur et al., 2002). To have any effect, probiotic strains must remain viable until they reach the intestinal tract. Bifidobacteria, classified as obligate anaerobes and implanted mostly throughout the colon, often present poor survival in fermented milk products and several authors have reported low viable counts of bifidobacteria in fermented milk (Jayamanne and Adams, 2009). The survival of probiotic organisms depends on various factors occurring during processing and formulation: $\mathrm{pH}$, oxidoreducing environment, presence of other microbes, temperature and time of storage, and water activity (Mattila-Sandholm et al., 2002). Oxygen is a powerful oxidant; it has a dramatic effect on $E_{h}$ value and on the viability of probiotic organisms during manufacturing and storage (Storz and Imlay, 1999; Talwalkar and Kailasapathy, 2004a,b).

Many techniques have been suggested to protect probiotic bacteria from oxygen toxicity in fermented milk. These include the following: use of special highoxygen consuming strains (Lourens-Hattingh and Viljoen, 2001), use of ascorbate and L-cysteine as oxygen scavengers (Dave and Shah, 1997a,b), microencapsulation (Kailasapathy, 2002), generation of adaptation to oxidative stress (Rallu et al., 2000), or use of adequate packaging material (Champagne et al., 2005). Pretreatment of milk could also be employed to lower oxygen content or to modify the $\mathrm{E}_{\mathrm{h}}$, using electroreduction, experimented with in the manufacture of milk (Bolduc et al., 2006a), and milk enriched with probiotic organisms (Bolduc et al., 2006b), or specific heat treatment in the manufacture of yogurt enriched with probiotic organisms, allowing the depletion of molecular oxygen and the liberation of sulfur-containing AA (Mortazavian et 
al., 2006a). The use of gas might also be an alternative for degassing milk. Milk is an oxidizing medium when in contact with air; nitrogen, which is neutral, can be used to remove oxygen from milk. Even so, the milk $E_{h}$ remains oxidizing, whereas hydrogen provides a reducing $\mathrm{E}_{\mathrm{h}}$ (below $0 \mathrm{mV}$; Martin et al., 2010). The production of lyophilized probiotic bacteria (Lactobacillus casei) was previously tested with an increase in survival during storage (Cachon et al., 2008). Indeed, after $60 \mathrm{~d}$ of conservation at ambient temperature, twice as much biomass was obtained in reduced conditions than with the control. Besides, it has recently been shown that the use of gas is a possible way to improve the organoleptic quality of dairy products (Martin et al., 2010). But the use of gas to produce acidified probiotic-enriched dairy foods has never been investigated.

The objective of the present study was to determine if producing fermented probiotic dairy products using milk without oxygen (nitrogen degassing) or reduced milk (nitrogen-hydrogen degassing) affects the survival of a probiotic strain, Bifidobacterium bifidum, over 28 d of storage.

\section{MATERIALS AND METHODS}

\section{Microorganisms and Culture Conditions}

The strains Lactobacillus delbrueckii ssp. bulgaricus LB 340 and Streptococcus thermophilus TA 60 were obtained from the EA 4181 GPMA research unit (Université de Bourgogne, Dijon, France). The strain $B$. bifidum CIP 56.7 was obtained from the Pasteur Institute collection (CIP), France. Stock cultures were prepared with subsequent storage at $-80^{\circ} \mathrm{C}$. Cells from thawed stock cultures were inoculated in $10 \mathrm{~mL}$ of de Man, Rogosa, and Sharpe (MRS) medium (Biokar Diagnostic, Beauvais, France) for L. delbrueckii ssp. bulgaricus, 10 $\mathrm{mL}$ of mMRS medium [MRS supplemented with $0.05 \%$ cysteine (wt/vol)] for B. bifidum, and $10 \mathrm{~mL}$ of M17 lactose (0.5\%) medium (Difco Laboratories, Elancourt, France) for Strep. thermophilus. The cultures were incubated overnight and used to inoculate $100 \mathrm{~mL}$ of their respective media. The flasks were incubated in static conditions and the optical density at $600 \mathrm{~nm}$ was monitored with a Perkin Elmer LS 50B fluorescence spectrophotometer (Perkin Elmer, Shelton, CT).

\section{Preparation of Fat-Free Fermented Milk Under Different $E_{h}$ Conditions}

For this study, organic skimmed ultra-high temperature (UHT) milk (Lactel, Laval, France) was used and $2 \%$ (wt/vol) of low-heat skim milk powder (Eurosérum, St. Martin Belle Roche, France) was added to fortify the skim milk (corresponding to 33-35 g/L of protein; Martin et al., 2010). The fortified milk was stirred for $4 \mathrm{~h}$ after addition of the skim milk powder and heated to $45^{\circ} \mathrm{C}$. It was then processed under different gaseous conditions. Different $\mathrm{E}_{\mathrm{h}}$ conditions were applied in an anaerobic chamber (Bactron I, Sheldon Manufacturing, Inc., Cornelius, OR) by gas bubbling for $4 \mathrm{~h}$ with a gas flow of $20 \mathrm{~mL} / \mathrm{min}\left[\mathrm{N}_{2}\right.$ or $\mathrm{N}_{2}$ plus $4 \%(\mathrm{vol} / \mathrm{vol}) \mathrm{H}_{2}\left(\mathrm{~N}_{2^{-}}\right.$ $\left.\mathrm{H}_{2}\right)$ ]. Experiments were also conducted without any gas bubbling (control milk) to obtain standard fermented milk. After the bubbling procedure, when applied, the mixture was fermented using $5 \times 10^{6} \mathrm{cfu} / \mathrm{mL}$ of each starter culture and $5 \times 10^{8} \mathrm{cfu} / \mathrm{mL}$ of the probiotic strain. The $\mathrm{pH}$ was recorded and when it reached 4.6 the fermented milks were cooled to $4^{\circ} \mathrm{C}$ for $1 \mathrm{~h}$ and stored at this temperature in Hungate tubes (Dutscher, Brumath, France) to maintain the intended $\mathrm{E}_{\mathrm{h}}$ attained after bubbling various gases.

\section{$E_{h}$ and $\mathrm{pH}$ Measurements}

The $\mathrm{pH}$ was monitored using a combined $\mathrm{pH}$ electrode (Inlab 405, Mettler-Toledo, Paris, France). The $\mathrm{pH}$ electrode was cleaned with a pepsin/ $\mathrm{HCl}$ solution and was calibrated using 2 calibration buffers ( $\mathrm{pH} 4$ and 7; PolyLabo, Paris, France). The $\mathrm{E}_{\mathrm{h}}$ was monitored using a combined platinum redox electrode (Pt4805, Mettler-Toledo) referred to as the $\mathrm{Ag} / \mathrm{AgCl}$ system and cleaned by polishing with a fine alumina powder (Aluminum oxide; VWR Prolabo, Lyon, France) before use to restore the platinum surface (Jacob, 1970). Electrodes were controlled in tap water. Three measurements in tap water were compared and were within the confidence interval of their mean value (calculated at $20 \mathrm{mV}, 95 \%$ confidence level) to ensure correct measurement (Abraham et al., 2007). For $\mathrm{N}_{2}$ and $\mathrm{N}_{2}-\mathrm{H}_{2}$ conditions, $\mathrm{pH}$ and $\mathrm{E}_{\mathrm{h}}$ measurements were carried out in the Bactron I anaerobic chamber (Sheldon Manufacturing, Inc.).

\section{Data Acquisition of $\mathrm{pH}$ and $E_{h}$ Profiles}

The $\mathrm{pH}$ and $\mathrm{E}_{\mathrm{h}}$ electrodes and the temperature sensor were connected to a controlled interface (ELIT multichannel $\mathrm{pH}$ meter/redox meter computer interface; Fisher Bioblock Scientific, Illkirch, France) that enabled real-time data acquisition on a computer. The $\mathrm{pH}$ and the measured redox potential $\left(\mathbf{E}_{\mathrm{m}} ; \mathrm{mV}\right)$ were recorded simultaneously. Based on the standard electrode value $\left(\mathbf{E}_{\mathbf{r}}\right)$ at the temperature of fermentation $\left(\mathrm{E}_{\mathrm{r}}\right.$ $=191 \mathrm{mV}$ ), the $\mathrm{E}_{\mathrm{m}}$, expressed in comparison with the reference electrode $\mathrm{Ag} / \mathrm{AgCl}$, were converted into $\mathrm{E}_{\mathrm{h}}$ values (redox potential expressed in comparison with the hydrogen electrode, $\mathrm{E}_{\mathrm{h}}=\mathrm{E}_{\mathrm{m}}+\mathrm{E}_{\mathrm{r}}$ ). The decrease 
in the $\mathrm{pH}$ of the medium indirectly modifies the $\mathrm{E}_{\mathrm{h}}$ (Nernstian response of the redox electrode). The $\mathrm{E}_{\mathrm{h}}$ was then expressed as $\mathrm{E}_{\mathrm{h}}$ at a given $\mathrm{pH}$ value, $\mathrm{pH} 7\left(\mathrm{E}_{\mathrm{h} 7}\right)$ according to the following equation $\mathrm{E}_{\mathrm{h} 7}=\mathrm{E}_{\mathrm{h}}-\alpha \times$ $(7-\mathrm{pHx})$, where $\alpha$ is the $\mathrm{E}_{\mathrm{h}}-\mathrm{pH}$ correlation factor and $\mathrm{pHx}$ is the $\mathrm{pH}$ of the medium. This factor $\alpha$ is determined experimentally by measuring the variation of $\mathrm{E}_{\mathrm{h}}$ with $\mathrm{pH}$ using lactic acid. For the milk used in this study, a variation in $\mathrm{E}_{\mathrm{h}}$ of $38 \mathrm{mV} / \mathrm{pH}$ unit at $45^{\circ} \mathrm{C}$ was measured. The $\mathrm{E}_{\mathrm{h} 7}$ values were $+441 \mathrm{mV}( \pm 4 \mathrm{mV})$ in the non-gassed milk, $+391 \mathrm{mV}( \pm 19 \mathrm{mV})$ in the milk gassed with $\mathrm{N}_{2}$, and $-310 \mathrm{mV}( \pm 17 \mathrm{mV})$ in the milk gassed with the $\mathrm{N}_{2}-\mathrm{H}_{2}$ mixture.

\section{Acidification Rate}

The $\mathrm{pH}$ values were processed mathematically to calculate the acidification rate $(\mathrm{dpH} / \mathrm{dt}, \mathrm{pH}$ unit/h), allowing the maximum acidification rate $\left(\mathrm{V}_{\mathrm{m}}^{\mathrm{a}} ; \mathrm{pH}\right.$ unit/h), the time at which this rate occurred $\left(\mathrm{T}_{\mathrm{m}}^{\mathrm{a}} ; \mathrm{h}\right)$, and the $\mathrm{pH}$ at which this maximum occurred $\left(\mathrm{pH}_{\mathrm{m}}^{\mathrm{a}} ; \mathrm{pH}\right.$ unit/h; Cachon et al., 2002) to be determined.

\section{Bacterial Enumeration}

Bacterial counts of B. bifidum and L. delbrueckii ssp. bulgaricus were obtained by spread-plating $(0.5 \mathrm{~mL})$ the appropriate peptone-water dilution using an Eddy Jet Spiral Plater (IUL SA, Barcelona, Spain) on mMRS-cysteine agar adapted according to Vinderola and Reinheimer (1999; MRS supplemented with $0.5 \mathrm{~g}$ of cysteine- $\mathrm{HCl} / \mathrm{L}, 2.4 \mathrm{~g}$ of lithium chloride/L, $0.015 \mathrm{~g}$ of nalidixic acid/L, $0.01 \mathrm{~g}$ of neomycin sulfate/L, and $0.01 \mathrm{~g}$ of paromomycin sulfate/L; Sigma Chemical Co., Castle Hill, Australia) or MRS, respectively. Plates were then incubated in anaerobic conditions (Anaerocult A; Merck, Darmstadt, Germany) at $37^{\circ} \mathrm{C}$ for $48 \mathrm{~h}$ (B. bifidum) or $42^{\circ} \mathrm{C}$ for $24 \mathrm{~h}$ (L. delbrueckii ssp. bulgaricus). Bacterial counts of Strep. thermophilus were obtained by spread-plating $(0.5 \mathrm{~mL})$ the appropriate peptone-water dilution on Strep. thermophilus agar (ST agar) using an Eddy Jet Spiral Plater (IUL SA) and incubating the plates at $37^{\circ} \mathrm{C}$ for $24 \mathrm{~h}$ in aerobic conditions. All cells were plated on agar before and after milk fermentation, and during storage (d 1, 14, and 28). Colonies were counted with a Countermat Flash Colony Counter (IUL SA, Barcelona, Spain).

\section{Statistical Analysis}

The experimental data were presented as mean values and variations with respect to mean values were pre- sented as standard deviations. An ANOVA was carried out on the mean values using SigmaPlot Software v11.0 (SPSS Inc., Chicago, IL). The values were compared using the Tukey test at $P<0.05$, and different letters were used to indicate statistically significant differences between values.

\section{RESULTS AND DISCUSSION}

\section{Evolution of $\mathrm{pH}$ and $\mathrm{E}_{\mathrm{h}}$ During Fermentation}

Evolution of $\boldsymbol{E}_{h \%}$. The evolution of $\mathrm{E}_{\mathrm{h} 7}$ measured in fermented milk as a function of time is presented in Figure 1A. The $\mathrm{E}_{\mathrm{h} 7}$ of control milk and milk gassed with $\mathrm{N}_{2}$ decreased during fermentation (respectively around 100 and $20 \mathrm{mV}$ ), contrary to $\mathrm{E}_{\mathrm{h} 7}$ of milk gassed with $\mathrm{N}_{2}-\mathrm{H}_{2}$, which remained relatively stable (around $-280 \mathrm{mV}$ after about $3.1 \mathrm{~h}$ of fermentation). Furthermore, no significant differences were observed between milk fermented with or without $B$. bifidum. The $\mathrm{E}_{\mathrm{h} 7}$ decrease is most probably related to starter growth and fermentation, causing the reduction of the oxygen in milk to water (Jacob, 1971; Cachon et al., 2002; Martin et al., 2010). A recent study showed that for Lactococcus lactis, a lactic acid bacterium that reduces milk $\mathrm{E}_{\mathrm{h} 7}$ to $-220 \mathrm{mV}$, thiol groups located on the bacterial cell surface appear to be the main components that are able to reduce milk after oxygen removal (Michelon et al.). Nevertheless, L. delbrueckii ssp. bulgaricus and Strep. thermophilus are weak reducing strains (Cachon et al., 2002; Brasca et al., 2007), and $\mathrm{E}_{\mathrm{h} 7}$ at the end of fermentation remained oxidant, except with $\mathrm{N}_{2}-\mathrm{H}_{2}$. Bifidobacterium bifidum is able to reduce milk to -100 $\mathrm{mV}$ (data not shown), but is a slow reducing strain and, in our study, the fermentation time was too short to reach such an $E_{h 7}$. During storage, changes in $E_{h 7}$ were observed; on d 28 it reached $+215 \mathrm{mV}( \pm 13 \mathrm{mV})$, $+178 \mathrm{mV}( \pm 8 \mathrm{mV})$, and $-187 \mathrm{mV}( \pm 15 \mathrm{mV})$, respectively, for the control milk, the milk gassed with $\mathrm{N}_{2}$, and the milk gassed with $\mathrm{N}_{2}-\mathrm{H}_{2}$. At the end of storage, negative $\mathrm{E}_{\mathrm{h}}$ values were still observed in the milk gassed with $\mathrm{N}_{2}-\mathrm{H}_{2}$.

Evolution of $\boldsymbol{p H}$. Acidification profiles of fermented milk made under different gaseous conditions are presented in Figure 1B. After addition of the starter culture and the probiotic strain to milk, the $\mathrm{pH}$ changed slowly for $1 \mathrm{~h}$, which was in agreement with previous results (Amice-Quemeneur et al., 1995). Thereafter, the $\mathrm{pH}$ decreased steadily until it reached $\mathrm{pH} 4.6$ when the fermented milks were cooled to stop enzymatic and metabolic bacterial activity and to avoid post-acidification phenomena. The evolution of the $\mathrm{pH}$ during acidification was similar in the 3 conditions employed and the time to reach the final $\mathrm{pH}\left(\mathrm{T}_{\text {gel }}\right)$ was not statisti- 

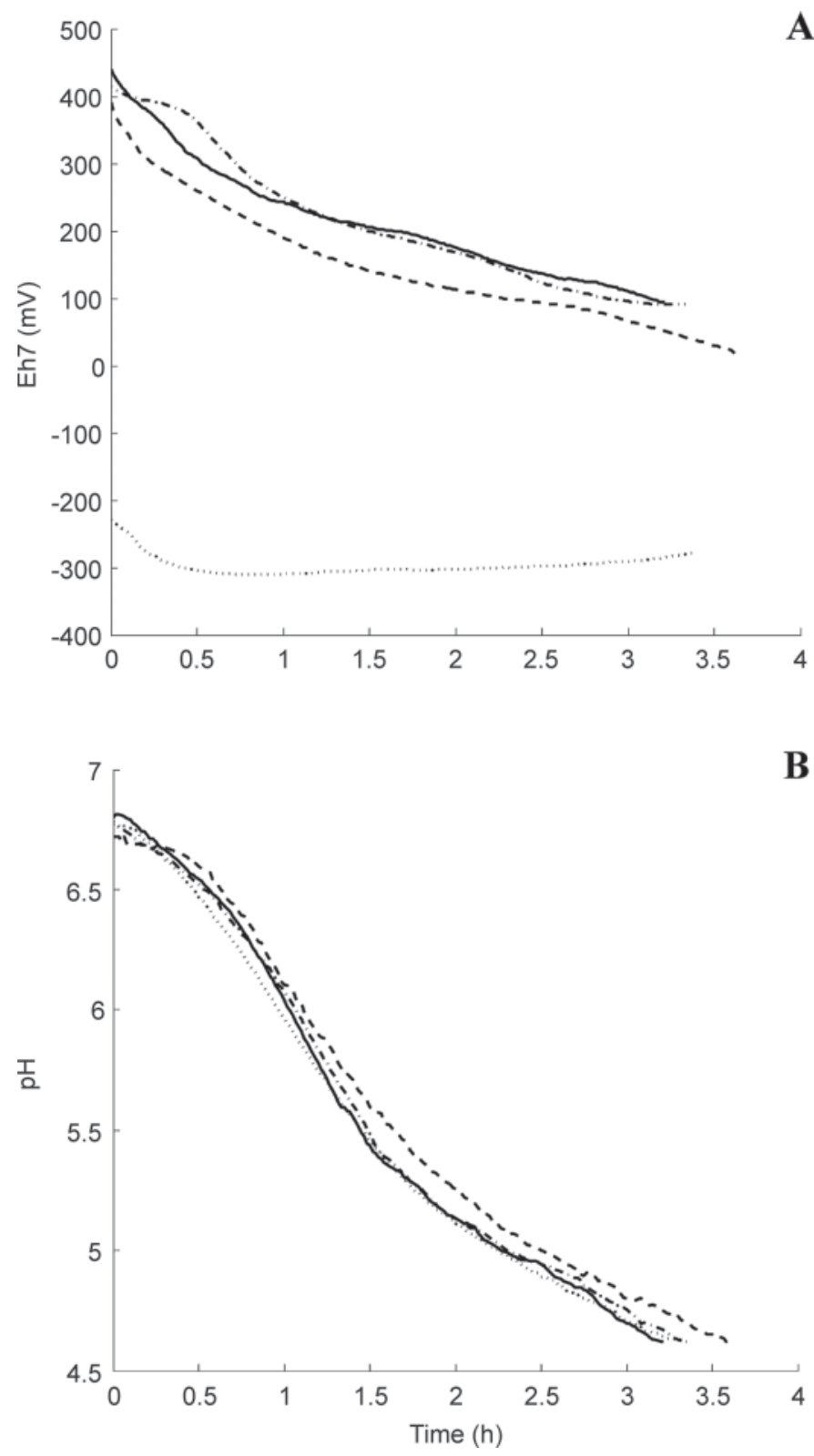

Figure 1. Evolution of the oxidoreduction (redox) potential at $\mathrm{pH}$ $7\left(\mathrm{E}_{\mathrm{h} 7} ; \mathrm{A}\right)$ and $\mathrm{pH}(\mathrm{B})$ during fermentation of milk. Different gaseous conditions were applied to milk: control with probiotic strain (solid line), control without probiotic strain (dashed/dotted line), gassed with $\mathrm{N}_{2}$ (dashed line), or gassed with $\mathrm{N}_{2}-\mathrm{H}_{2}$ (dotted line).

cally different (about $3.2 \mathrm{~h}$ ). Moreover, the $\mathrm{V}_{\mathrm{m}}^{\mathrm{a}}$, $\mathrm{T}_{\mathrm{m}}^{\mathrm{a}}$, and the $\mathrm{pH}_{\mathrm{m}}^{\mathrm{a}}$ were analyzed (Table 1). In our experiments, no statistical differences between the acidification of the control milk, the milk gassed with $\mathrm{N}_{2}$, or the milk gassed with $\mathrm{N}_{2}-\mathrm{H}_{2}$ were observed. Using gas allows the $\mathrm{E}_{\mathrm{h}}$ to be manipulated without affecting the $\mathrm{pH}$ of the environment, contrary to cysteine or ascorbate, which have a negative effect on the textural and cul-
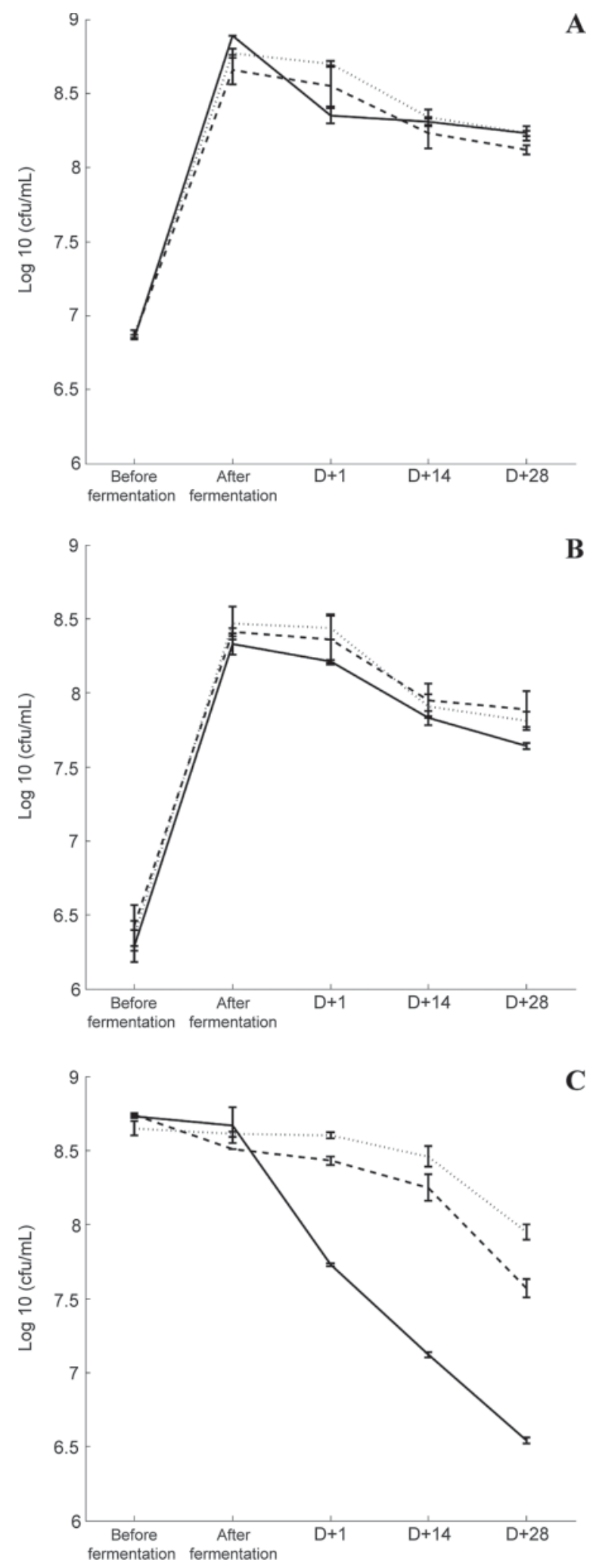

Figure 2. Evolution of a population of Streptococcus thermophilus (A), Lactobacillus delbrueckii ssp. bulgaricus (B), and Bifidobacterium bifidum $(\mathrm{C})$ during fermentation and storage (at days 1, 14, and 28). Different gaseous conditions were applied to milk: control (solid line), gassed with $\mathrm{N}_{2}$ (dashed line), or gassed with $\mathrm{N}_{2}-\mathrm{H}_{2}$ (dotted line). 
Table 1. Mean values of the kinetic parameters calculated from acidification rates during fermentation of milk ${ }^{1}$

\begin{tabular}{lccc}
\hline Gas & $\mathrm{T}_{\text {gel }}(\mathrm{h})$ & $\mathrm{V}_{\mathrm{m}}^{\mathrm{a}}(\mathrm{pH}$ unit/h) & $\mathrm{T}_{\mathrm{m}}^{\mathrm{a}}(\mathrm{h})$ \\
\hline Control (+Bifidobacterium bifidum) & $3.14(0.05)^{\mathrm{a}}$ & $-1.35(0.10)^{\mathrm{b}}$ & $1.27(0.07)^{\mathrm{c}}$ \\
Control (-B. bifidum) & $3.20(0.03)^{\mathrm{a}}$ & $-1.25(0.06)^{\mathrm{b}}$ & $1.43(0.11)^{\mathrm{c}}$ \\
$\mathrm{N}_{2}$ & $3.33(0.28)^{\mathrm{a}}$ & $-1.16(0.08)^{\mathrm{b}}$ & $1.17(0.03)^{\mathrm{c}}$ \\
$\mathrm{N}_{2}-\mathrm{H}_{2}$ & $3.22(0.12)^{\mathrm{a}}$ & $-1.17(0.00)^{\mathrm{b}}$ & $1.32(0.13)^{\mathrm{c}}$ \\
\hline
\end{tabular}

${ }^{\mathrm{a}-\mathrm{c}}$ Same superscript letters within a column indicate that groups were not significantly different at $5 \% \alpha$ risk (ANOVA).

${ }^{1}$ Different gaseous conditions were applied to milk: control (with or without probiotic strain), gassed with $\mathrm{N}_{2}$, or gassed with $\mathrm{N}_{2}-\mathrm{H}_{2}$. $\mathrm{T}_{\text {gel }}=$ acidification time; $\mathrm{V}_{\mathrm{m}}^{\mathrm{a}}=$ maximum acidification rate; $\mathrm{T}_{\mathrm{m}}^{\mathrm{a}}=$ time to reach $\mathrm{V}_{\mathrm{m}}^{\mathrm{a}}$.

tural properties of yogurt by suppressing growth of yogurt strains (Talwalkar and Kailasapathy, 2004a,b). Besides, as previously shown (Martin et al., 2010), no significant variation in $\mathrm{pH}$ during storage between $\mathrm{d} 1$ and 28 occurred.

\section{Bacterial Growth During Fermentation and Evolution of Survival During Storage}

Evolution of Bacterial Counts During Milk Fermentation. As shown in Figure 2, only yogurt starters grew during fermentation. As expected, after analyzing the acidification profiles of fermented milk with or without a probiotic strain (Figure 1B and Table 1 ), the acidification activity of B. bifidum was lower than those of the yogurt bacteria. Moreover, no growth of $B$. bifidum occurred during the fermentation phase (Figure 2C). The use of gas did not enhance the growth of the 3 strains, which is again in correlation with the fact that gas bubbling has no effect on acidification profiles.

Evolution of Survival During Storage of the Fermented Dairy Product. It has been previously reported that incorporation of ascorbic acid (Dave and Shah, 1997b) or cysteine (Dave and Shah, 1997a), electroreduction (Bolduc et al., 2006b), or specific heat treatment (Mortazavian et al., 2006b) in fermented milk causes a decrease in oxygen content and an $E_{h}$ which results in better survival of probiotic bacteria.

In aerobic conditions, a decrease in the bacterial count was observed for the 3 strains during storage. This decrease was moderate for Strep. thermophilus and L. delbrueckii ssp. bulgaricus, $0.66 \log$ (Figure 2A) and $0.69 \log$ (Figure 2B), respectively, after $28 \mathrm{~d}$ of storage at $4^{\circ} \mathrm{C}$, and drastic for $B$. bifidum, with a decrease of $2.12 \log$ after $28 \mathrm{~d}$ (Figure 2C). The difference in behavior between probiotic strains and starters could be explained by the fact that starters do not have the same sensitivity to oxygen and $\mathrm{pH}$ as do probiotic strains. Indeed, B. bifidum showed a moderate ability to deal with environmental stress, especially high oxygen (Bolduc et al., 2006b) and acidic environments (Sun and Griffiths, 2000). Oxygen toxicity results from the effect of activated oxygen compounds, including superoxide, hydrogen peroxide, and hydroxyl radicals (Talwalkar and Kailasapathy, 2004a). Superoxide dismutase and catalase, the key enzymes that scavenge toxic oxygen metabolites, are absent in bifidobacteria, as is NADH peroxidase (which converts $\mathrm{H}_{2} \mathrm{O}_{2}$ into $\mathrm{H}_{2} \mathrm{O}$ ) in B. bifidum (Shimamura et al., 1992).

Gas bubbling before fermentation had a significant positive effect on the survival of $B$. bifidum during storage. Indeed, after $28 \mathrm{~d}$ of storage at $4^{\circ} \mathrm{C}$, prior bubbling with $\mathrm{N}_{2}$ or $\mathrm{N}_{2}-\mathrm{H}_{2}$ allowed greater survival of the probiotic strain with differences in bacterial counts of 1.18 and $1.46 \log (P<0.05)$, respectively, in comparison with the control (Figure 2C). This result is concordant with the literature describing the positive effect of the absence of oxygen on the survival of bifidobacteria (Dave and Shah, 1997a; Bolduc et al., 2006b). Because the increase in survival of $B$. bifidum during storage is not due to improved growth, we can suppose that the cells adapted during fermentation (Ouvry et al., 2002). Moreover, in all conditions (control, $\mathrm{N}_{2}$, and $\mathrm{N}_{2}-\mathrm{H}_{2}$ ), the increase in $\mathrm{E}_{\mathrm{h} 7}$ during storage was accompanied by a decrease in survival of $B$. bifidum. But contrary to electroreduced milk, which showed positive $E_{h}$ values on d 7 (Bolduc et al., 2006b), in our study, $\mathrm{N}_{2}-\mathrm{H}_{2}$ bubbling and storage in Hungate tubes allowed negative values to be maintained and better survival of $B$. bifidum. In contrast, gas bubbling had no influence on survival during storage of Strep. thermophilus and $L$. delbrueckii ssp. bulgaricus. Once again, this could be explained by the difference in sensitivity to oxygen and the combined effect of putative oxidative and $\mathrm{pH}$ stress on the 3 strains.

Further to the elimination of oxygen (due to $\mathrm{N}_{2}$ ) and the addition of a reduction compound $\left(\mathrm{N}_{2}-\mathrm{H}_{2}\right)$, the increase in survival in anaerobic and reduced conditions could be due to cellular compounds, such as thiol groups (-SH), being maintained in reduced form. Thiol groups are important compounds both for reducing activity 
(Michelon et al., 2010) and for antioxidant properties and resistance to oxidative stress (Balcerczyk and Bartosz, 2003; Patsoukis and Georgiou, 2004). The effect of gases on lipid composition and membrane fluidity (Ouvry et al., 2002) could also contribute to enhanced survival.

\section{CONCLUSIONS}

This study shows that low $\mathrm{E}_{\mathrm{h}}$, modified using $\mathrm{N}_{2}-\mathrm{H}_{2}$ gas, enhanced B.bifidum survival during storage without having a negative effect on acidification parameters because it did not affect growth or survival of yogurt strains. Furthermore, use of a gaseous environment similar to that in the large intestine (absence of oxygen and $\mathrm{E}_{\mathrm{h}}$ below $0 \mathrm{mV}$ due to the presence of $\mathrm{H}_{2}$ ) further enhanced survival during storage. Preservation of reducing cell surface proteins or modification of lipids could be responsible for this phenomenon.

\section{ACKNOWLEDGMENTS}

This work was supported by research grants from Senoble (Jouy, France), the Association Nationale de la Recherche et de la Technologie (ANRT, Paris, France) and the FUI Probiotique program supported by Vitagora (Dijon, France). The authors thank Christine Rojas (EA 4181 GPMA research unit, Université de Bourgogne, Dijon, France) for her technical assistance in managing the strain collection.

\section{REFERENCES}

Abraham, S., R. Cachon, B. Colas, G. Feron, and J. De Coninck. 2007. Eh and $\mathrm{pH}$ gradients in camembert cheese during ripening: Measurements using microelectrodes and correlations with texture. Int. Dairy J. 17:954-960.

Amice-Quemeneur, N., J.-P. Haluk, J. Hardy, and T. P. Kravtchenko. 1995. Influence of the acidification process on the colloidal stability of acidic milk drinks prepared from reconstituted nonfat dry milk. J. Dairy Sci. 78:2683-2690.

Balcerczyk, A., and G. Bartosz. 2003. Thiols are main determinants of total antioxidant capacity of cellular homogenates. Free Radic. Res. 37:537-541.

Bolduc, M.-P., L. Bazinet, J. Lessard, J.-M. Chapuzet, and J.-C. Vuillemard. 2006a. Electrochemical modification of the redox potential of pasteurized milk and its evolution during storage. J. Agric. Food Chem. 54:4651-4657.

Bolduc, M.-P., Y. Raymond, P. Fustier, C. P. Champagne, and J.C. Vuillemard. 2006b. Sensitivity of bifidobacteria to oxygen and redox potential in non-fermented pasteurized milk. Int. Dairy J. 16:1038-1048.

Brasca, M., S. Morandi, R. Lodi, and A. Tamburini. 2007. Redox potential to discriminate among species of lactic acid bacteria. J. Appl. Microbiol. 103:1516-1524.

Cachon, R., C. Delbeau, G. Feron, and H. Ledon. 2008. Method of modifying the viability of a lyophilized microorganism by treating the growth medium thereof with gases. L'Air Liquide, assignee. US Pat. No. 20080268524

Cachon, R., S. Jeanson, M. Aldarf, and C. Divies. 2002. Characterisation of lactic starters based on acidification and reduction activities. Lait 82:281-288.
Champagne, C. P., N. J. Gardner, and D. Roy. 2005. Challenges in the addition of probiotic cultures to foods. Crit. Rev. Food Sci Nutr. 45:61-84.

Dave, R. I., and N. P. Shah. 1997a. Effect of cysteine on the viability of yoghurt and probiotic bacteria in yoghurts made with commercial starter cultures. Int. Dairy J. 7:537-545.

Dave, R. I., and N. P. Shah. 1997b. Effectiveness of ascorbic acid as an oxygen scavenger in improving viability of probiotic bacteria in yoghurts made with commercial starter cultures. Int. Dairy J. 7:435-443

Fuller, R. 1991. Probiotics in human medicine. Gut 32:439-442.

Jacob, H. E. 1970. Redox potential. Pages $91-123$ in Methods in Microbiology. Vol. 2. Academic Press, London, UK.

Jacob, H. E. 1971. Redox potential in bacterial cultures. Z. Allg. Mikrobiol. 11:691-734.

Jayamanne, V. S., and M. R. Adams. 2009. Modelling the effects of $\mathrm{pH}$, storage temperature and redox potential $\left(\mathrm{E}_{\mathrm{h}}\right)$ on the survival of bifidobacteria in fermented milk. Int. J. Food Sci. Tech. 44:1131-1138

Kailasapathy, K. 2002. Microencapsulation of probiotic bacteria: Technology and potential applications. Curr. Issues Intest. Microbiol. 3:39-48.

Kaur, I. P., K. Chopra, and A. Saini. 2002. Probiotics: Potential pharmaceutical applications. Eur. J. Pharm. Sci. 15:1-9.

Kerckhoffs, A. P. M., M. Samsom, and G. P. van Berge Henegouwen. 2006. Sampling microbiota in the human gastrointestinal tract. Pages 25-50 in Gastrointestinal Microbiology. A. C. Ouwehand and E. E. Vaughan, ed. Taylor \& Francis, Inc., New York, NY.

Lourens-Hattingh, A., and B. C. Viljoen. 2001. Yogurt as probiotic carrier food. Int. Dairy J. 11:1-17.

Mackie, R. I., A. Sghir, and H. R. Gaskins. 1999. Developmental microbial ecology of the neonatal gastrointestinal tract. Am. J. Clin. Nutr. 69:1035S-1045S.

Martin, F., N. Cayot, C. Vergoignan, L. Journaux, P. Gervais, and R. Cachon. 2010. Impact of oxidoreduction potential and of gas bubbling on rheological properties of non-fat yoghurt. Food Res. Int. $43: 218-223$.

Mattila-Sandholm, T., P. Myllärinen, R. Crittenden, G. Mogensen, R. Fondén, and M. Saarela. 2002. Technological challenges for future probiotic foods. Int. Dairy J. 12:173-182.

Michelon, D., S. Abraham, B. Ebel, J. De Coninck, F. Husson, G. Feron, P. Gervais, and R. Cachon. 2010. Contribution of exofacial thiol groups in the reducing activity of Lactococcus ssp. lactis FEBS J. 277:2282-2290.

Mortazavian, A. M., M. R. Ehsani, S. M. Mousavi, J. A. Reinheimer, Z. Emamdjomeh, S. Sohrabvandi, and K. Rezaei. 2006a. Preliminary investigation of the combined effect of heat treatment and incubation temperature on the viability of the probiotic micro-organisms in freshly made yogurt. Int. J. Dairy Technol. 59:8-11.

Mortazavian, A. M., M. R. Ehsani, S. M. Mousavi, S. Sohrabvandi, and J. A. Reinheimer. 2006b. Combined effects of temperaturerelated variables on the viability of probiotic micro-organisms in yogurt. Aust. J. Dairy Technol. 61:248-252.

Ouvry, A., Y. Waché, R. Tourdot-Maréchal, C. Diviès, and R. Cachon. 2002. Effects of oxidoreduction potential combined with acetic acid, $\mathrm{NaCl}$ and temperature on the growth, acidification, and membrane properties of Lactobacillus plantarum. FEMS Microbiol. Lett. 214:257-261.

Patsoukis, N., and C. Georgiou. 2004. Determination of the thiol redox state of organisms: New oxidative stress indicators. Anal. Bioanal. Chem. 378:1783-1792.

Pearson, C. B., and H. W. Walker. 1976. Effect of oxidation-reduction potential upon growth and sporulation of Clostridium perfringens. J. Milk Food Technol. 39:421-425.

Rallu, F., A. Gruss, S. D. Ehrlich, and E. Maguin. 2000. Acid- and multistress-resistant mutants of Lactococcus lactis: Identification of intracellular stress signals. Mol. Microbiol. 35:517-528.

Shimamura, S., F. Abe, N. Ishibashi, H. Miyakawa, T. Yaeshima, T. Araya, and M. Tomita. 1992. Relationship between oxygen sensitivity and oxygen metabolism of Bifidobacterium species. J. Dairy Sci. $75: 3296-3306$ 
Storz, G., and J. A. Imlay. 1999. Oxidative stress. Curr. Opin. Microbiol. 2:188-194

Sun, W., and M. W. Griffiths. 2000. Survival of bifidobacteria in yogurt and simulated gastric juice following immobilization in gellanxanthan beads. Int. J. Food Microbiol. 61:17-25.

Talwalkar, A., and K. Kailasapathy. 2004a. A review of oxygen toxicity in probiotic yogurts: Influence on the survival of probiotic bacteria and protective techniques. Compr. Rev. Food Sci. Food Saf. 3:117-124.

Talwalkar, A., and K. Kailasapathy. 2004b. The role of oxygen in the viability of probiotic bacteria with reference to L. acidophilus and Bifidobacterium spp. Curr. Issues Intest. Microbiol. 5:1-8.
Unden, G., M. Trageser, and A. Duchêne. 1990. Effect of positive redox potentials $(>+400 \mathrm{mV})$ on the expression of anaerobic respiratory enzymes in Escherichia coli. Mol. Microbiol. 4:315-319.

Vinderola, C. G., and J. A. Reinheimer. 1999. Culture media for the enumeration of Bifidobacterium bifidum and Lactobacillus acidophilus in the presence of yoghurt bacteria. Int. Dairy J. 9:497-505.

Wilson, M. 2008. Bacteriology of Humans. Blackwell Publishing Ltd., London, UK. 